\title{
Using our agrobiodiversity: plant-based solutions to feed the world
}

\author{
Sven-Erik Jacobsen $^{3}$ • Marten Sørensen ${ }^{1} \cdot$ Søren Marcus Pedersen ${ }^{2} \cdot$ Jacob Weiner $^{1}$
}

Accepted: 25 June 2015 / Published online: 8 September 2015

(C) The Author(s) 2015. This article is published with open access at SpringerLink.com

\begin{abstract}
The growing global demand for food poses a serious challenge to mankind: How can we provide an increasing world population with an adequate, reliable and nutritious food supply? We argue that this can best be achieved through the utilization of biodiversity and the inclusion of marginal arable lands for agricultural production, while maintaining a broad gene pool to secure the potential for future plant production and supporting rural agricultural communities. We present several specific examples of how an emphasis on agricultural biodiversity can provide the basis for a nutritional, reliable, culinary and sustainable food production, and analyse the advantages, limitations and risks of an increased focus on agrobiodiversity. We conclude that the potential for approaches based on the preservation and development of existing agrobiodiversity has not been given sufficient attention in the current scientific and political debates concerning the best strategy to keep pace with global population growth and increasing demand for food. An emphasis on agrobiodiversity is the basis for the most appropriate strategies if the goal is to feed the world in the twenty-first century.
\end{abstract}

Sven-Erik Jacobsen

seja@plen.ku.dk

1 Department of Plant and Environmental Sciences, Faculty of Science, University of Copenhagen, Thorvaldsensvej 40, 1871 Frederiksberg, Denmark

2 Institute of Food and Resource Economics, University of Copenhagen, Rolighedsvej 25, 1958 Frederiksberg, Denmark

3 Department of Plant and Environmental Sciences, Faculty of Science, University of Copenhagen, Højbakkegaard Alle 13, DK-2630 Taastrup, Denmark
Keywords Underutilized species · Andean crops · Food production $\cdot$ Sustainability

Contents

1. Introduction

1.1 Strengths: advantages of agrobiodiversity solutions

1.1.1 Genetic diversity

1.1.2 Climate change resilience

1.1.3 Nutrition

1.1.4 Traditional diets

1.1.5 Local importance

1.2 Weaknesses

1.2.1 Yield

1.2.2 Low awareness

1.2.3 Low status

1.2.4 Limited variety development

1.3 Opportunities

1.3.1 Utilization of marginal lands

1.3.2 Reduce malnutrition and famine

1.3.3 Improve soil fertility

1.3.4 Conventional breeding efforts

1.3.5 Clean drinking water

1.3.6 Attractive high-end products

1.4 Threats

1.4.1 Extension service and market organization

1.4.2 Multinational seed companies

1.4.3 Consumer acceptability

1.4.4 Overexploitation of fragile lands

1.4.5 Increased retail prices

2. Recommendations

3. General discussion

4. Conclusion

5. References 


\section{Introduction}

According to the FAO (2004), agrobiodiversity is defined as "the variety and variability of animals, plants and microorganisms that are used directly or indirectly for food and agriculture, including crops, livestock, forestry and fisheries. It comprises the diversity of genetic resources (varieties, breeds) and species used for food, fodder, fibre, fuel and pharmaceuticals. It also includes the diversity of non-harvested species that support production (soil micro-organisms, predators, pollinators), and those in the wider environment that support agro-ecosystems (agricultural, pastoral, forest and aquatic) as well as the diversity of the agro-ecosystems." In this paper, we focus on plant agrobiodiversity for food production exclusively. Although we realize the overall importance of the other classes mentioned in the FAO definition, and while agrobiodiversity also has much to offer in temperate climates, our geographical context is the area between the tropics of Cancer and Capricorn, where the majority of developing countries are located, as are the major part of the dry, warm and in general marginal agricultural areas.

In a recent paper (Jacobsen et al. 2013), we argue that a strategy based on the utilization of existing plant agrobiodiversity offers much more promise than a focus on genetic technology if the objective is to feed the world's growing population within the coming decades. Here we address the following question: Which selection criteria should be implemented to ensure the highest level of sustainability and reliability for the biodiversity-based strategy of crop development we espouse? Based on a critical analysis of a wide range of underutilized crops, we present here a list of relevant criteria, which can increase the probability of an intelligent utilization of biodiversity.

According to UNCTAD (2013), farming in rich and poor nations alike would benefit from a shift from monocultures towards greater varieties of crops and a reduced reliance on fertilizers and other inputs (Bullock et al. 2007). There is broad agreement that food production must increase significantly within the next 40 years if it is to keep pace with the forecast population growth expected to reach nine billion by 2050 (Kahane et al. 2013; Mba et al. 2012). This has to be accomplished even though arable land, with limited water and energy, and these challenges are exacerbated by climate change (ISF 2011). At present, one billion people in the world face starvation and a further two billion suffer one or more micronutrient deficiencies, especially vitamin $\mathrm{A}$, iodine and iron, often lumped as hidden hunger (Alnwick 1996).

A UN report states that we must achieve a reorientation of our agricultural systems towards modes of production that are highly productive and highly sustainable and that contribute to the progressive realization of the human right to adequate food (De Schutter 2011). Agro-ecology delivers advantages that are complementary to conventional approaches such as breeding high-yielding varieties.

Modern agriculture focuses on the cultivation of a few major staple crops, rice, maize and wheat, which provide half of the global human requirement for carbohydrates, proteins and calories (Table 1) (Lopez-Noriega et al. 2012). Furthermore, among the 100-120 crop plant species used today for extensive food production, $95 \%$ of human dietary energy originates from only 20 of these (Parry et al. 2009). The human diet is increasingly dependent on an ever-shorter list of food plants. In addition, genetically modified (GM) crops currently account for 170 million ha of the global 1.5 billion ha of arable land, i.e. $8.8 \%$, exclusively represented by soybean (Glycine max Merr.), maize (Zea mays L.), cotton (Gossypium L. spp.) and rapeseed (Brassica napus L. (ISAAA.ORG 2013)). This development does not bode well for the maintenance of global agrobiodiversity. Although 7000 plant species in the world have been used for food, over the past few 50 years, 6 species cover $50 \%$ of the arable land: wheat (Triticum aestivum L.), soybean, maize, rice (Oryza sativa L.), barley (Hordeum vulgare L.) and rapeseed (Fig. 1).

Agriculture is the primary source of foods and, in the past decade, also increasingly a source of bioenergy. However, modern, intensive agriculture is generally harmful to the environment, resulting in contamination of drinking water, soil degradation and erosion, with negative effects on biodiversity (Frison et al. 2011). Large modern farms specialize in either livestock or few crop species, grown as monocultures of genetically uniform individuals. Large fields reduce the extent of field margins and hedgerows with their reserves of biodiversity, while extensive use of industrial fertilizers causes loss of soil organic matter and degrades soil productivity (FAO 1983; Acton and Gregorich 1995; Amaranthus et al. 2009). The adoption of herbicide- and pesticide-tolerant genetically modified (GM) crops increases the threat to biodiversity considerably (ISAAA.ORG 2013).

Two major problems of global agriculture require immediate attention and have resulted in intensified search for underutilized crops with potential to enhance global food security: (1) price instability of agricultural produce, especially since 2007, due to crop failures, rising demands and increased production for bioenergy, exacerbated by a growing population and improved income in some developing countries, and (2) the globalization of agricultural markets and the concentration of food supply within a few, large international corporations, resulting in worldwide dominance of a very limited number of crops. In this process, underutilized crops with unique advantages for global food security have been ignored, despite increased interest in these crops due to new consumer demands (Ahmad and Javed 2007; Mba et al. 2012; Padulosi et al. 2006). Almost all agricultural research and development have been focussed on the few, dominant crop species. 
Fig. 1 Development of global arable area with six major crops (1963-2012), based on FAO statistics (FAO 2010)

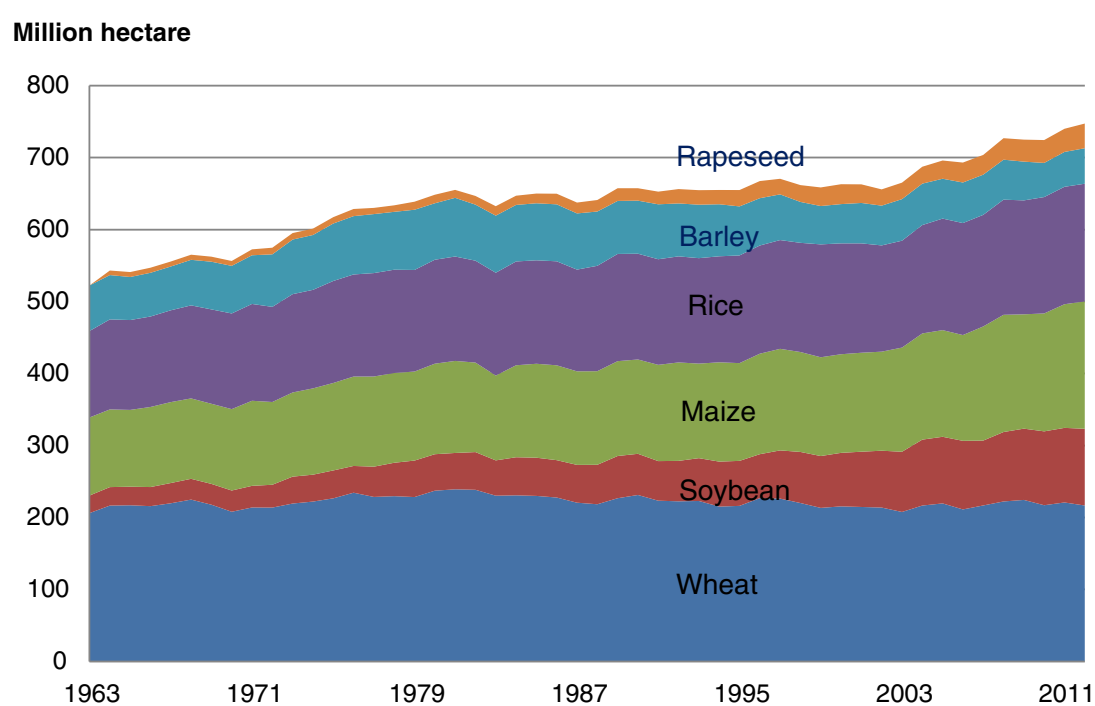

Increased food production in the face of the above mentioned obstacles will require increased access to genetic resources (Juma 2011). For example, coming changes in the growth seasons of various crops due to climate change require specific mitigating crop breeding efforts (Burke et al. 2009). The prerequisites of such breeding programs encompass not only knowledge of existing practices, including local selection criteria but also the conservation of a wide genetic pool of crop resources among existing breeds and their wild relatives as a source of genes necessary to cope with changes in agricultural production. Therefore, agrobiodiversity, that is the genetic diversity of cultivated species, i.e. not including genetically modified genotypes, should be a central element in sustainable agricultural development (Conner and Mercer 2007; Huang et al. 2002; Kahane et al. 2013; Salinger 2012; Welch and Graham 2004). The concept of sustainability is based on the principle that today's needs must be addressed without compromising the needs of future generations (Lichtfouse et al. 2009). Sustainable agriculture represents an attractive alternative for solving fundamental and applied issues related to food production based on ecological principles (Lal 2008).

In a recent paper, we addressed the claims that genetic modification (GM) technology should be able to achieve the goals described above (Jacobsen et al. 2013). We concluded that, in the vast majority of cases, the proposed 'high-tech' GM solutions have failed to achieve these goals but represent a very different agenda, obscuring more appropriate 'low-tech' solutions that rely on existing agrobiodiversity of proven value.

Our objective of this paper is to analyse the strengths, limitations, potential and risks of agrobiodiversity in several ecosystems, with examples of genetic resource conservation. We also consider the potential of some lesser-known crops for securing and increasing global production of food in sufficient quality and quantity.

The study is in broad terms based on an expert-oriented Technology Assessment (TA) and Impact Assessment (IA), applied for the study and evaluation of new technologies, based on the relevance of new discoveries and their market, risks and ethical implications (Pedersen 2003; van den Ende et al. 1998). An IA has become a widely used method in public policy research TA (Tran and Daim 2008), and in environmental impact assessment (Bond and Pope 2012; Pope et al. 2013). IA is an appropriate tool to assess the impact of a technology in the early phase of the development or in relation to market introduction for a technology-driven problem. In the early phase of their development, most innovations are driven by a technology push from companies or researchers. After the technology matures, the market takes over its development.

Since we see little evidence of polarization among stakeholders concerning increased agrobiodiversity as such, we take this assessment approach, while recognizing that stakeholder involvement could be relevant in a broader impact assessment if the study is extended to compare with other technologies such as GMO.

Here we analyse the development of agro-ecosystems with a high degree of biodiversity and estimate the cultural impact of these developments. Following the basic structure of a 'SWOT' analysis (Strength, Weaknesses, Opportunities and Threats), we describe the advantages (Strengths) of an increased focus on agrobiodiversity, the limitations (Weaknesses) of this approach, some examples of what it can achieve (Opportunities), and some of the risks (Threats) that may occur from an emphasis on agrobiodiversity. SWOT analysis has its origins in the 1960s (Learned et al. 1965). It provides a framework for assessing a planning strategy, a direction of a business proposition or just an idea. Normally, in 
business situations, it is structured as a $2 \times 2$ matrix grid that focuses on two internal dimensions (Strengths and Weaknesses) and two external dimensions (Opportunities and Threats). A variation of SWOT analysis is the TOWS matrix, in which various factors are identified and paired to stimulate new strategies (Dyson 2004). In the current study, we regard agrobiodiversity as an idea or technology like any other business proposition, and the term agrobiodiversity is assessed according to these four dimensions. A SWOT analysis is a flexible tool; therefore, a strict categorization of the SWOT dimensions (according to 'internal' and 'external' factors) can be limiting. In that sense, we have used a more open interpretation of the model (Jackson et al. 2003; Businessballs 2014). A SWOT analysis can - in principle - be used in any decision-making situation when a desired end-state, i.e. objective, has been defined. By combining the SWOT approach with in-depth fact finding and validation from current literature and scientific reports, we attempt to assess the overall impact of an increased adoption of agrobiodiversity in society. We conclude with recommendations for policy makers.

\subsection{Strengths: advantages of agrobiodiversity solutions}

\subsubsection{Genetic diversity}

Crop genetic diversity is concentrated in centres of origin, as defined by the Russian botanist and geneticist Nikolaj Vavilov (1951, 1992, 1997; Ladizinsky 1998). Farmers in these centres, who still practice traditional agriculture, cultivate local varieties. These are known as landraces - selected locally over many generations - and which frequently possess many traits associated with their wild relatives. Together, landraces and their wild relatives are the richest repositories of crop genetic diversity (FAO 1990).

Agricultural diversity can furnish the impoverished third world farmer, who often lives under difficult conditions with few or no economic resources, with a better livelihood and less dependence on large international corporations. It can generate income, secure reliable food supply and guarantee improved nutrition and health among family members (Porter et al. 2010). In areas where climatic conditions are unstable, such as in many developing countries, local agriculture traditionally relies on a range of crops rather than just a few crops. This strategy of agricultural bet hedging increases the reliability of food production in the face of seasonal variation.

\subsubsection{Climate change resilience}

As a result of the dramatic growth in total global food and bioenergy demand, $\mathrm{CO}_{2}$ emissions and competition for land will increase as a consequence of the ever growing share of the world's consumer's switch to diets increasingly consisting of meat, dairy products and processed foods (Parry et al. 2009).
Soil salinity, drought and other climatic extremes are expected to increase in frequency due to climate change (Pachauri and Reisinger 2007). Some crops, but not all, are adapted to climatic changes; however, the mere increasing of agrobiodiversity will have a positive impact on climate change mitigation.

Numerous examples of how traditional crops contribute to resilient production exist; e.g. the Bambara groundnut (Vigna subterranea (L.) Verdc.) is a nutritious legume originating from West Africa and cultivated throughout sub-Saharan Africa (Heller et al. 1997), known for its drought tolerance and nutritional value (Collinson et al. 1996; Andika et al. 2008). Millets - a range of small seeded cereals belonging to several grass genera - generally possess both excellent drought tolerance as well as valuable nutritional qualities (Bala Raví 2004). For cold climates, cañahua (Chenopodium pallidicaule Aellen), an underutilized Andean seed crop that has remarkable frost tolerance (Jacobsen et al. 2005, 2007; Rojas et al. 2010), is yet another little-known crop of great promise. Another excellent hardy crop is the drumstick tree (Moringa oleifera Lam.) from NW India, also known as the 'miracle tree', which has a drought tolerance trait as well as highly nutritious leaves (Souza and Kulkarni 1993). Several species cultivated in India, including the neotropical custard apple (Annona squamosa L.), Indian gooseberry or amla (Phyllanthus emblica L.), ber or Indian jujube (Zizyphus mauritiana Lam.), tamarind (Tamarindus indica L.) and neem (Azadirachta indica A. Juss.), are also recognized for drought tolerance and their ability to thrive on poor soils and marginal lands (Hegde 2009). This also applies to numerous crop species from the Andes, where adaptation and resilience of local crops have fed the Andean people for millennia (Halloy et al. 2005; Perez et al. 2010) with species that can cope with extreme climatic conditions found on the high Andean plateau, where drought, soil salinity, hailstorms, frost, etc. are common (Adolf et al. 2013; Jacobsen et al. 2003a, b; Razzaghi et al. 2011, 2012). These crops are quinoa (Chenopodium quinoa Willd.), amaranth (Amaranth spp.), cañahua and Andean lupine (Lupinus mutabilis Sweet), all of which have a high tolerance to soil salinity, drought and other climatic extremes, and are expected to increase in frequency due to climate change (Pachauri and Reisinger 2007). Millets, sorghum (Sorghum bicolor (L.) Moench) and teff (Eragrostis tef (Zuccagni) Trotter), indigenous leafy vegetables and fruits, and a range of legumes, represent a wealth of potentially important crops. Crop biodiversity can play an important role in the reduction of pesticide use, as disease and pest pressures become reduced when diversity increases. Pesticides are a major factor affecting biological diversity globally (Isenring 2010). Furthermore, while traditional crops may not be adapted to all types of climate change, they are generally hardier in the face of climate challenges than modern varieties, which produce high yield, but only under good conditions and with high inputs. 


\subsubsection{Nutrition}

Traditional crops are often nutrient-rich and constitute the basis of diets in rural communities (Rudebjer et al. 2011). Several studies have documented how underutilized species can be strategic allies in fighting food and nutritional insecurity, including 'hidden hunger' (de Benoist et al. 2008; WHO 2009). There are hundreds of wild and cultivated species of leafy vegetables grown and consumed in Africa, and there is a huge potential for improved food security through the use and development of these species (Smith and Eyzaguirre 2007). The nutritional value of many underutilized, traditionally cultivated crops is high, with ample amounts of micronutrients, antioxidants and essential amino acids. Some of these crops have both medicinal and nutritive value. Underutilized crops provide opportunities to enrich diets with nutritionally healthier foods while simultaneously they make food and food culture more varied and interesting. These crops could play an important role in a healthier and more diverse diet. We present some examples:

An investigation of 270 households in Burkina Faso carried out in 2005 (Lamien et al. 2009) looked at the daily consumption of local fruits, such as jackal berry (Diospyros mespiliformis Hochst. ex A.DC.), desert date (Balanites aegyptiacus (L.) Delile) and ber (Ziziphus mauritiana Lam.). The work revealed that these species are used regularly by the local populations and play a pivotal role in balancing local diets because of their high nutritional value, satisfying human requirements of minerals, vitamins and sugar, and to a lesser extent proteins and lipids. Leaves of amaranth (Amaranthus hybridus L., Amaranthus retroflexus L. and Amaranthus tricolor L.), pumpkins (Cucurbita moschata Duchesne, Cucurbita pepo L. and Cucurbita argyrosperma K. Koch) and African nightshade (Solanum scabrum Mill.) all contain high levels of minerals and vitamins (Ogle and Grivetti 1985; Lyimo et al. 2003). Non-cultivated leafy vegetables consumed in rural areas of Africa are even richer in iron, zinc and pcarotene, e.g. spiderwisp (Cleome gynandra L.) and amaranth (Msuya et al. 2009; Uusiku et al. 2010).

\subsubsection{Traditional diets}

Minor crops are traditionally utilized in many ways, making them interesting from a culinary perspective. Despite their local value, the continued availability of many of these crops is endangered due to competition on unequal terms from bulk products and food aid in the form of industrially produced commercial varieties of rice, maize and wheat. The limited marketing of underutilized crops is often due to the need for specific processing and their local image as 'poor people's food', as well as insufficient research and breeding. For example, as mentioned by FAO (1997), there are numerous promising local landraces and in Asia varieties of rice and sweet potato (Ipomoea batatas (L.) Lam.) that could be further developed through plant breeding.

Traditional cultures make provisions for the health of future generations by providing special nutrient-rich foods for pregnant women and growing children, traditional forms of birth control to increase the time between births and by teaching principles of a healthy diet to the next generation.

\subsubsection{Local importance}

While global plant-based food production is based on very few crops, this is not always the case at the local and regional levels where a wide range of lesser-known crops are extremely important for food, forage, industrial uses and cultural practices (CGIAR 2010). Many rural communities around the world depend on crop species not listed among the internationally traded crops, so they lie outside mainstream agricultural research and development. These neglected and underutilized species are part of rich and diverse agroecosystems and constitute important elements of human culture. They also play a vital role in the upkeep of sustainable livelihoods, human well-being and ecosystem health and stability (Hawtin 2007).

\subsection{Weaknesses}

\subsubsection{Yield}

Many of the underutilized crops have low yields, which may be attributed to their cultivation on marginal lands with low inputs and at low plant densities, and they may be difficult to harvest because of low height, shattering of seed, etc. (Heller 1996). These problems could be addressed with plant breeding since these crops are much less developed and domesticated than the major crops.

\subsubsection{Low awareness}

Traditional crops are increasingly neglected as farmers consider them less profitable due to lack of demand. Consumers are either unaware of their existence or exclude them from their more simplified diets, and researchers set them aside (Baena et al. 2012). Despite the benefits of many traditional minor crops and rising demand for vegetarian, gluten-free food products, etc., the available information on underutilized crops is largely limited to local communities and a few specialized research institutes. In addition, research on the potential for food production in developing countries and traditional uses is often not adequately prioritized, as research is focussed on the major crops, internationally traded on a large scale (Kahane et al. 2013). 


\subsubsection{Low status}

Traditional food crops may be linked to small-scale farmers and therefore have been of little interest to urban consumers. This is reflected in the prestige associated with the improvement of cultivated plants. Due to the lack of consideration by contemporary research and development, the potential value of underutilized species is greatly underestimated, resulting in the current, unprecedented loss of crop species, varieties and associated traditional knowledge at the farm level. These factors have a noticeable impact on food and nutritional security of poor, small hold farming communities and their ability to cope with climate change. Similarly, the loss of food culture associated with their traditional diets means that the local communities also lose a vital part of their culture and identity (Padulosi et al. 2006).

\subsubsection{Limited variety development}

While traditional breeding methods may result in major yield increases in minor crops, the impact will not necessarily be noticed, as the area under cultivation with these crops is insignificant compared to the area covered by the major crops. If modern plant breeding methods were applied, even further improvements could be achieved by breeding for local conditions, but the privatization of plant breeding in much of the world has meant that breeding efforts are exclusively focussed on few major crops (Makoni et al. 2012).

\subsection{Opportunities}

\subsubsection{Utilization of marginal lands}

An estimated 7000 plant species have been used for food globally. Many of the underutilized species are essential to farmers' livelihoods, particularly in marginal environments with rain-fed agriculture (Rudebjer et al. 2011). Existing biodiversity can facilitate the enlargement of the available lands for agricultural production. While yields in such areas probably never can be high by world standards, they do represent potential food for consumption and sale, which can be managed sustainably. Quality parameters may be of interest for many of these species.

\subsubsection{Reduce malnutrition and famine}

The highly intensive agricultural systems of home gardens are some of the most diverse and most productive systems in the world (Eyzaguirre and Linares 2004; Galluzzi et al. 2010). Although they are usually highly labour intensive and small, home gardens nonetheless provide direct benefits in terms of production, income and nutrition for millions of small-scale farmers throughout the world. This agricultural biodiversity can reduce year-to-year variation in production, contributing to yield stability as shown in studies from Brazil and Senegal (Nair 2001; Brun et al. 1989). The crops are characterized by their favourable nutritional qualities and their reliability in production. Already at the $1995 \mathrm{UN}$ conference in Rio de Janeiro on 'Environment and Sustainable Development', there was a general consensus that the world's food supply and nutrition are most secure if based on the broadest possible range of crops. In a world where meeting the food demand of a growing population continuously becomes a more serious challenge, local biodiversity has much to offer.

\subsubsection{Improve soil fertility}

There are obvious benefits from cultivating a broader range of crops, i.e. pulses, vegetables and root crops in preference to only cereals. For example, different crops have different root systems, extracting water and nutrients from varying depths. The nutrients contained in the roots and aboveground parts are then made available to the following crop after their unharvested biomass is incorporated into the soil. This improves soil structure, increases soil microbial activity and decreases the building up of soil-borne pests and diseases. Legumes play a key role as they fix nitrogen, some of which remains in the soil for subsequent crops (Connor et al. 2011).

\subsubsection{Conventional breeding efforts}

When lesser-known crops are improved with intensive, traditional breeding methods, and improved remarkable yield increases are achievable. Modern breeders should be able to replicate the achievements of the last century on promising underutilized crops much quicker than it took for the major crops, by using our modern understanding of genetics (Mayes et al. 2012). Numerous promising alternatives to the world's major crops exist, and many of these are potentially high yielding. The application of traditional plant breeding methods to minor crops often offers a more efficient and economically attractive approach, since they are already well adapted to local agricultural conditions and are culturally accepted and utilized. Low-tech breeding results compare favourably with modern molecular breeding techniques, even when applied to the major crops (Murphy 2007). Low-tech solutions are often much more effective and less failure-prone, but commercially of less interest, as they are less profitable to large international corporations, which explains why GM crop development attracts considerably more economic support (Jacobsen et al. 2013). The main argument for the current prioritizing of continued improvement of few major crops over minor crops existed prior to the advent of GM crops: A $50 \%$ yield increase, which for a number of minor crops is clearly achievable at a relatively low cost, will have less of an effect on the global food supply than a yield improvement in 
one of the five major crops of $1 \%$. From the perspective of feeding the world's population, this argument is short sighted, serving the economic interests of large seed-producing corporations, not local farmers or consumers. Minor crops can become major crops if they are marketed. The promotion of a crop variety or species requires availability of high-quality seed for propagation. In close collaboration, farmers and researchers together hold the potential to identify and analyse those underutilized species for high yield, for tolerance to abiotic and biotic stresses, and with market potential, thereby benefiting local development and global biodiversity. A global effort is needed to further develop crops already adapted to specific ecological conditions.

If we consider the food production and distribution system, especially the role of large agri-business corporations, then an improvement in some minor crops grown by poor farmers for subsistence and sale locally will contribute more towards feeding undernourished populations than an increase in major crops produced at industrial scale, even in the short run. If the goal is to feed the world's growing populations, the breeding strategy to increase crop production in the world should be based on marker-assisted selection and free of the political and economic interests associated with GM technologies (Tester and Langridge 2010).

\subsubsection{Clean drinking water}

When growing underutilized crop species, the risk of contaminating the sources of drinking water is almost non-existent, as such crops are usually grown organically with low inputs. With herbicide-tolerant species, which has been the main focus of GM crop development, it is possible to increase pesticide application without damaging the crop; therefore, unknown health and environmental risks through pollution of groundwater are causes of considerable concern (Cerdeira et al. 2007). The prediction by laboratory researchers that degradation of the herbicides in the soil profile will occur quickly, eliminating the risk of polluting the groundwater has been repeatedly disproved (Sanchís et al. 2012). Glyphosate is now found in groundwater, in Denmark (WHO 2013), the UK (Buffin and Jewell 2001) and the USA (USGS 2013). In Germany, levels 5-20 times higher than the upper limits in drinking water were found in urine (Brändli and Reinacher 2012). Development of underused traditional, lower-input crops is much more environmentally friendly than high-tech solutions.

\subsubsection{Attractive high-end products}

Crop diversification is a key component for enhancing adaptation and resilience of production systems in the face of climate change. Greater demand for underutilized species can play an important role nutritionally, while in addition they serve to maintain livelihood options for the rural and urban poor (Padulosi et al. 2011).

There is a growing interest in exotic foods, which have become readily available as a result of cheap and accessible transport and efficient marketing. The consumer demand for novel products has increased dramatically in recent years, and supermarkets today offer foods from many corners of the world, products that were available exclusively in a few regions of the world only a few decades ago (Rudebjer 2009; Rudebjer et al. 2011). Market globalization may place the products from small-scale farmers under threat but may also bring new opportunities. A growing demand for exotic, organic and fair-trade foods has created global value chains that potentially provide farmers with new sources of income. Acerola (Malpighia emarginata Moçiño \& Sessé), camu-camu (Myrciaria dubia (Kunth) McVaugh) and naranjilla or lulo (Solanum quitoense Lam.) are successful recent examples. We see this in Latin America, where the situation is already changing for a few of the traditional crops, such as the yambean or jícama (Pachyrhizus erosus (L.) Urban) from Mexico, and quinoa from the Andes, which have both been discovered and gained accesses to international markets. In addition to traditional uses, several Andean crops have demonstrated their potential for the development of new products. Some 'new' crops reached the global market several centuries ago (e.g. potato and tomato) while others have done so only recently (e.g. quinoa and maca [Lepidium meyenii Walp.]).

\subsection{Threats}

\subsubsection{Extension service and market organization}

Education and information are important factors in the adoption of new farming methods and technologies (Feder et al. 1985). In 2005, there were an estimated 500,000 agricultural extension workers worldwide, with $95 \%$ of these working with public agricultural extension systems (Aker 2011). In many developing countries, however, farm advice and extension services may have difficulties in reaching small-scale farmers. Extension services - if provided at all — are often the responsibility of governmental advisory services and universities or are provided directly from private seed and supply companies. Occasionally, services are offered by cooperatives in developing countries, but rarely by farmers' associations or independent private consultants as seen in most European countries. In recent years, however, the diffusion of mobile phones has made it easier to provide information and facilitate adoption of new cropping systems directly from companies and organizations, even in some African countries; Manobi ${ }^{\circledR}$, an African mobile data services operator, provides innovative services to small businesses like farmers, fishermen, vulnerable women and children, as well as large companies to 
encourage economic and social development [http://www2. manobi.com/].

The organization of the market supply chain in developing countries may differ significantly depending on region and crop. It is useful to distinguish between export cash crops, stable food crops and high-value crops like fruit and vegetables (Poulton et al. 2010). A common feature of stable food crops in for instance Africa is that the market chain consists of many buyers and sellers that seldom have access to financial assets or collateral. The market is often informal with little regulation and with significant price fluctuations due to local market and supply conditions. For cash crops, the market chain often consists of a few major processors or wholesale buyers that seek to establish a vertical coordination of services and investment for small-scale farmers. In these supply chains, important factors may be the quality and stable produce supplies (Poulton et al. 2010). A similar pattern is common to certain high-value crops, mainly horticultural crops. In developing countries, the supply chains serving supermarkets are growing rapidly with increased vertical coordination to ensure taste, quality and prices, and the retail sector and intermediaries often have the greatest market power in the food supply chains. They transfer risks and unexpected costs to farmers, which compromise innovation and modernization. A study from Turkey showed that the lack of capital among farmers, dependency between farmers and intermediaries, farm size and crop characteristics increase intermediaries' market power over farmers (Xhoxhi et al. 2014).

Lack of organization among farmers means that trade unions usually have little impact on salaries and education within the food supply chain. In 2001, the size of the informal sector, i.e. including agriculture, was 45,75 and $75-85 \%$ in Latin America, Africa and Asia, respectively (Gallin 2001). Labour in the informal sector is often unskilled and labourers have little influence on their salaries and working hours.

When introducing new crops, it is important to consider crop type, labour costs, market aspects and possibilities to provide the relevant information and extension services to farm households.

\subsubsection{Multinational seed companies}

In spite of the growing culinary demand for new plant-derived foods, agrobiodiversity remains under threat due to the globalizing economy and its concentration in the hands of a small number of international plant breeding companies. This reduces biodiversity by promoting industrial agricultural production that encourages large-scale, uniform monocrop systems rather than promoting community-based seed production (Jones and Rakotoarisaona 2007). In order to retain long-term, efficient and economically attractive possibilities for the utilization of agrobiodiversity, it is essential to consider the threats to the exploitation of existing biodiversity from agricultural industrialization. Plant breeding continues to be aimed at a few crop species rather than a wider focus on selected traits within the lesser-known biodiversity, such as tolerance towards weeds, pests and diseases as well as climate change (Grum 2009). As a result, few major crops dominate national and international commerce, production and agricultural research (Schmidhuber and Tubiello 2007).

\subsubsection{Consumer acceptability}

Some of the underutilized crops are locally associated with low-income groups, as they constitute the principal consumers within the society. Therefore, these food crops are considered of low status. The increasing demand for meat, as countries become more affluent, also has an influence on agricultural land use and, thus, on agrobiodiversity (Rudebjer et al. 2011).

\subsubsection{Overexploitation of fragile lands}

One example of overexploitation is the extremely fragile land of the southern Bolivian altiplano, where only one crop is produced on a commercial scale: quinoa. It has been a demonstration of how a highly sustainable, but delicate agricultural system may be disrupted when a sudden increase in demand occurs. This may lead to a system that is brought from a high level of stability to the verge of an ecological breakdown due to overexploitation of the marginally arable lands (Jacobsen 2011, 2012).

\subsubsection{Increased retail prices}

The commodity range of supermarkets is a powerful driving force behind agricultural change. The growing influence of the large international retailers on the supply chain has an impact on local agriculture, even in remote areas, because producers and consumers are connected in increasingly global markets. Supermarkets prefer a large, stable and reliable supply of goods, which can be a challenge for small producers with a local supply. Urbanization is linked to changes in food preferences, as consumers change from traditional, diverse diets to energy-rich, cheap, but often nutrient-poor, simplified diets (Rudebjer et al. 2011).

\section{Recommendations}

In the following, we present alternative solutions for new crops that could be produced on larger scale, based on existing agrobiodiversity. The examples represent crops at various stages of development, but all share the potential to become utilized at a much higher level than at present (Fig. 2). 


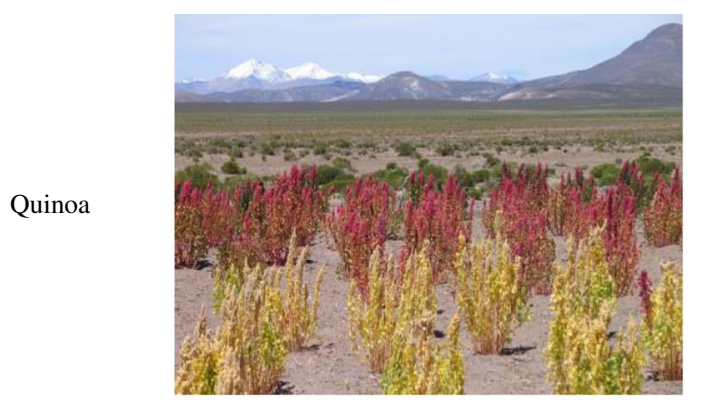

Bolivia

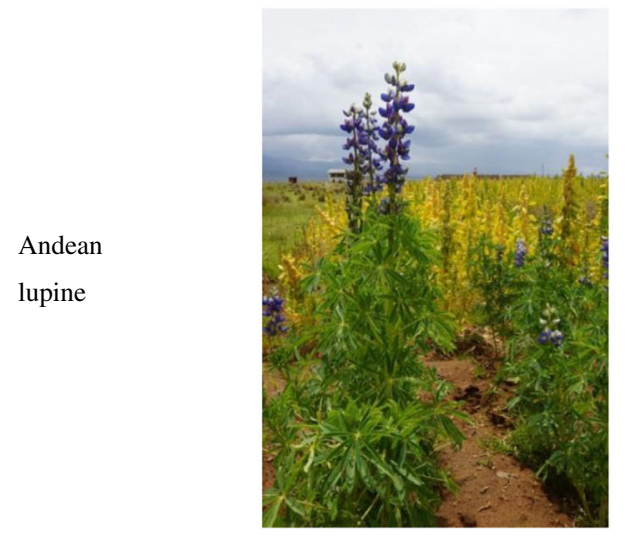

Bolivia

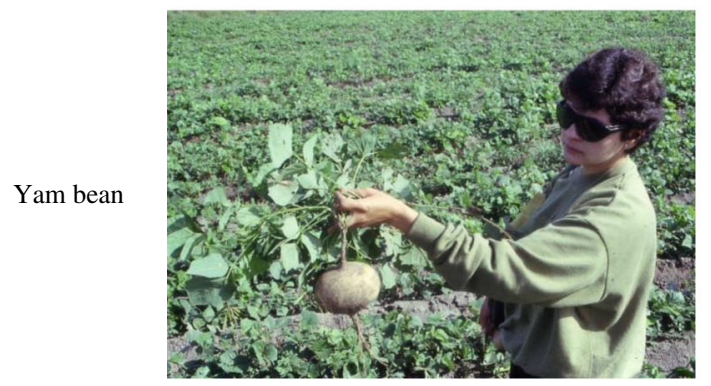

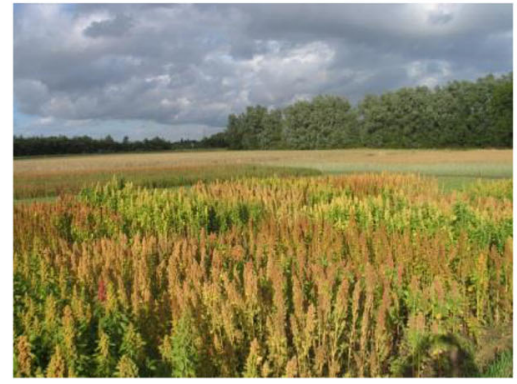

Denmark

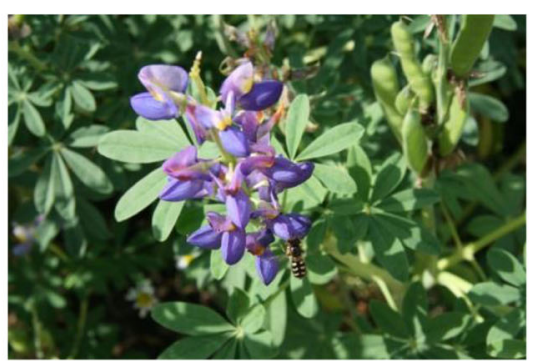

Denmark

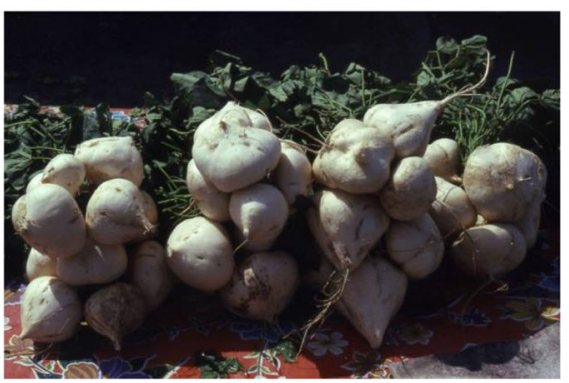

Mexico

Fig. 2 Photos of selected new crops from traditional and new growing areas. Photos: M. Sørensen and S.-E. Jacobsen

To quantify this is difficult, but as some are alternatives to major crops, the potential is huge.

Quinoa

The Food and Agriculture Organization of the United Nations (FAO) designated quinoa as one of this century's crops because it can both contribute towards securing the foods for the growing world population based on the crop's nutritional qualities (Repo-Carrasco et al. 2003; Stikic et al. 2012) and provide yield reliability under extreme growth conditions (Jacobsen et al. 2003a). The crop is not solely of interest to the rural poor, but also in the context of improving unhealthy lifestyles in the developed world. Only few years ago, quinoa was consumed almost exclusively by the rural Andean population, while in the major cities of Peru, Bolivia and Ecuador, the urban consumers did not take an interest in this low-status crop. The situation changed during the 1990s as a result of growing exports to North America and Europe (Jacobsen et al. 1994, 1996, 2012; Jacobsen 2003). At present, quinoa is consumed in many parts of the world, and in South America, it has achieved a new status (Jacobsen 1997; Jacobsen et al. 2003b). The success for quinoa as an export crop in Bolivia has led to problems of environmentally unsustainable overproduction in the southern high plains, putting even more emphasis on the importance of securing healthy cropping systems, and a diversification of production sites (Jacobsen 2011, 2012). In Denmark, the market for quinoa continues to grow steadily (Jacobsen et al. 2010). Most supermarkets stock quinoa, while newspapers and magazines regularly offer new appealing recipes. This demonstrates that diets can change and that consumers are interested in a variety of crops rather than just a few crops. 
Seed-

watermelon
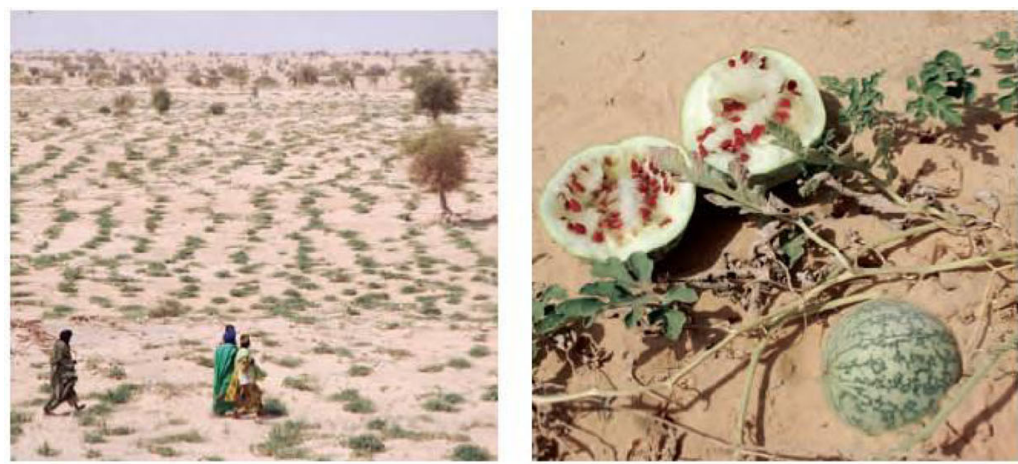

Mali

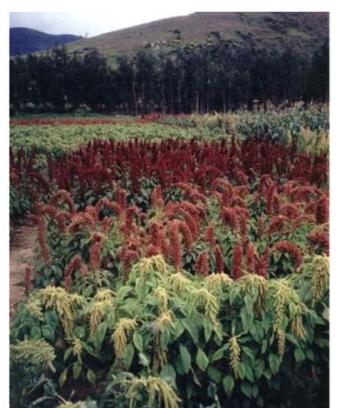

Peru

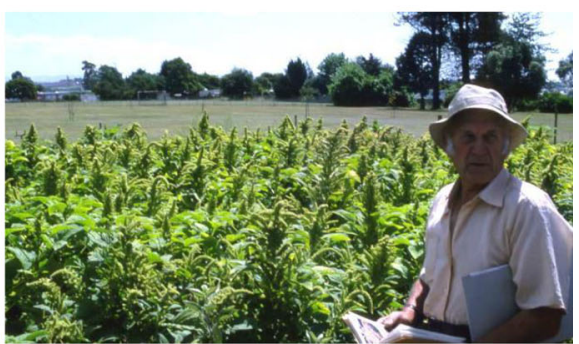

Tasmania

Nopal

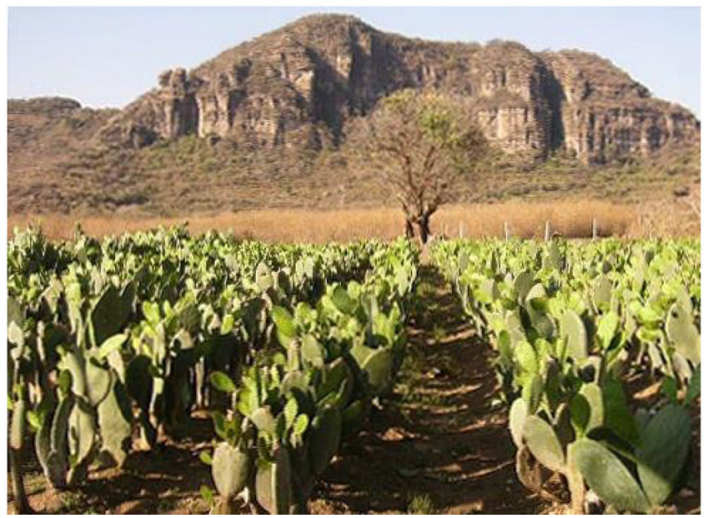

Mexico

Fig. 2 (continued)

In Bolivia, one of the most important centres of origin of cultivated plant species, there is growing awareness regarding the value of the local Andean crops both for local uses and overseas in the marketing initiatives targeted at the worldwide boom in consumer demand for quinoa. The southern plateau of Bolivia relies almost exclusively on the production of quinoa and the raising of llamas, which are two of the highest-priority products for the Bolivian government. Both are expected to contribute substantially towards the national income in the future (MDRyT 2009).

Quinoa is regarded as a coming new global crop (FAO 2013a, b) with trials underway in many parts of the world. Commercial production is established in France; breeding is taking place in Bolivia, Peru and other Andean countries, USA, Netherlands and Denmark (Bazile et al. 2013).

Amaranth (Amaranthus spp.)

As a C4 photosynthesis species, amaranth is adapted to high temperatures. Amaranth has already gained importance in various African countries as a leafy vegetable (Shackleton et al. 2009). It contains wide genetic variation in morphological characteristics, form, colour, agronomic behaviour, resistance to adverse factors and specificity of use. Some of the important traits to be preserved in gene banks are reduced seed shattering, larger seeds, adaptability to new environments, phenotypic plasticity and yield potential. 
Amaranth is well adapted to marginal land and holds a significant possibility for further adaptation due to its high genetic diversity and range of phenotypic plasticity (Rastogi and Shukla 2013). Combining these characteristics with its inherent tolerance to high temperatures, drought, poor soil conditions and the absence of major disease problems makes amaranth highly adaptable to adverse growing conditions (Jacobsen et al. 2003a, b). Its nutritionally desirable characteristics (Rastogi and Shukla 2013) and thus its potential to fulfil immediate food and nutritional demands of rural populations in agriculturally vulnerable areas add to the status of amaranth as a crop with properties applicable to climate change mitigation and food security..

The genus Amaranthus includes 87 species, of which 56 are native to the Americas, 17 in Europe and 14 in Australia (Mujica and Jacobsen 2003). Some of the African species with potential are Amaranthus graecizans L. and Amaranthus thunbergii Moq. The species of Amaranthus are found in cultivated or semi-cultivated forms, and many of them have become distributed worldwide, owing basically to their capacity of adaptation, as well as to the large quantity of seeds produced by each individual plant. The species known as grain amaranth are Amaranthus caudatus L., Amaranthus hypochondriacus L. and Amaranthus cruentus L.

Consumed similarly to quinoa, amaranth offers high nutritional value because of its composition of proteins, unsaturated fatty acids and dietary fibre as well as starch content. It contains sufficient levels of minerals and vitamins and substantial quantities of bioactive components such as phytosterols, squalene, fagopyritols and polyphenols. Amaranth is a gluten-free seed, and its composition offers many functional properties for feed and for human health, especially for nutritionally demanding consumers such as high-performance athletes, children, elderly, diabetics and celiacs. Available information on amaranth does, however, remain limited. Market potential is similar to that of quinoa, but with production in warmer areas of Latin America, Africa, USA and south Europe.

Yam-bean (Pachyrhizus spp.)

The Mexican yam-bean, locally known as jícama, has recently become the fastest-growing speciality vegetable in the US market (Sørensen 2004). There are several reasons for the success in the USA of a crop almost exclusively imported from Mexico: low content of lipids, highly digestible starch type, agreeable taste, crunchy apple-like texture and numerous possibilities for preparation. In addition, yam-bean is one of very few crops that combine efficient nitrogen fixation and associated protein content of a legume with the yield reliability of a root crop. Yam-beans, with an impressive climatic adaptation, are cultivated from sea level to 2000-m altitude in the Andes, from tropical rainforest in South America and the Far East to semi-arid zones in Central America and West Africa. No anti-nutritional compounds have been found in the edible root, and since types with dry matter content comparable to that of manioc (Manihot esculenta Crantz) exist, traditional starch-rich dishes may benefit from preparation with yam-bean (Zanklan et al. 2007). The yambean has the advantage of being propagated from seed with no need for storing vegetative planting material. Thus, the risk of loss of planting material and virus contamination is reduced. The genus originates in Latin America, but the Mexican jicama is now widely found in cultivation in India, China and in the Far Eastern tropics (Oré Balbin et al. 2007; Sørensen 1996; Sørensen et al. 1997a, b).

Nopal (Opuntia ficus-indica (L.) Mill. var. ficus-indica)

The Nopal cactus, which belongs to the genus Opuntia Mill. and grows in the central and northern part of Mexico, is best known for its fruits, called cactus pear (Robles-Contreras et al. 2008). In Mexico, the young, flat shoots, morphologically known as 'cladodes', have been consumed as a vegetable in salads and hot dishes for millennia. This crop provides a completely different type of product from other tropi$\mathrm{cal}$, drought-tolerant crops and hence complements oilrich seeds, e.g. jojoba (Simmondsia chinensis (Link) C.K. Schneid.), physic nut (Jatropha curcas L.) and fruits such as pumpkins (Cucurbita spp.), dates (Phoenix dactylifera $\mathrm{L}$.) and pomegranate (Punica granatum L.), in addition to other cactus species, e.g. red and yellow pitaya (Hylocereus undatus (Haw.) Britton \& Rose and Selenicereus megalanthus (K. Schum. ex Vaupel) Moran). A specialized form of photosynthesis known as crassulacean acid metabolism (CAM) allows the plant to survive and even grow under desert-like conditions. It must be considered an advantage to be able to produce vegetables from areas with very limited precipitation when considering the rapid desertification process in many continental centres, e.g. East Africa. 
Nopal cacti have several medicinal uses and do not nutritionally differ significantly from other betterknown vegetables (DeFelice 2004).

Seed-watermelon (Citrullus lanatus (Thunb.) Matsum. \& Nakai subsp. lanatus)

In dry African regions, there are several virtually unknown species or varieties of watermelon, which produce valuable foods under extreme semi-arid conditions. These watermelons are not like the wellknown watermelon fruits with which we are familiar. They are not sweet and red fleshed, but white inside, with numerous nutritious seeds that are used in traditional cooking. In Mali, watermelons of many different seed qualities constitute important sources of human food. The seeds are prepared as energy-rich snacks or used for flour, and oil can be extracted. In Tanzania, the fruit flesh of the pumpkin-like types is used as food, especially in periods when no other crop products are available, because the fruits can be stored for more than 6 months. The tsamma-watermelon is exceptionally drought and disease resistant, making it promising in the face of global climate changes. The biological diversity of local watermelon landraces is being studied by researchers, as is their potential as a source of income to poor rural families (Jensen et al. 2009). The objective is to gather information that will permit breeders and gene banks to identify local watermelon genetic resources with attractive traits of potential relevance in the future.

Coloured Brome (Bromus coloratus Steud.)

Ryegrass (Lolium perenne L.) based pastures are used very widely throughout the warm temperate world for their quick establishment, cheap seed, ease of management and reasonable productivity. However, there seems to be a lack of awareness that ryegrass has a number of shortcomings that affect the whole farming system. These include poor tolerance to drought and a grassgrub pest (larvae of the Tutaeruru beetle, Costelytra zealandica White), high alkaloid content produced by various ryegrass endophyte fungi and associated problems of reduced weight gains, increased dags (a dung-caked lock of wool around the hindquarters of a sheep), flystrike (myiasis), heat stress and staggers (Waghorn et al. 1999). In recent years, there has been an increase in the genetic modification of ryegrass to overcome these shortcomings (Faville et al. 2010). This endeavour has been challenged in New Zealand where non-ryegrass-based pastures have demonstrated production advantages and fewer pest problems, all leading to economic benefits and thus contributing to more sustainable pastoral systems (Musgrave and Daly 2004). An alternative to GM ryegrass is illustrated by the development of coloured brome. Originating in Argentina and Chile, this perennial grass has consistently outyielded ryegrass in comparative trials in Australia (Hall and Hurst 2012). It is endophyte free and therefore has none of the problems with animal health noted above. Not only more drought tolerant than ryegrass, coloured brome maintains its quality as a preferred feed for grazing animals for a longer period. It is proving to be an excellent alternative perennial grass for dryland warm temperate pastures receiving $>650$-mm annual rainfall.

Potato (Solanum spp.)

An example of a special initiative directed towards in situ conservation of agrobiodiversity is the Potato Park in Cusco, Peru. The objective of the Potato Park is to study the processes related to climate change impacts, to evaluate how the climate is changing, how it is projected to change in the future, and what the possible impacts of the change will be on local agriculture (CIP 2013).

The communities of the Potato Park maintain a relationship of respect and harmony with the earth (Pacha Mama). The area is a recognized centre of origin of native potatoes, with both domesticated and wild varieties. The conservation and celebration of this rich genetic diversity and habitats create multiple options for local subsistence, including agro-ecotourism and traditional and Novo Andina gastronomy, as well as natural medicines, cosmetics and functional food.

The Potato Park houses beautiful landscapes and cultivated land in terraced slopes, which date back to the Incan times, and it contains a rich wild and domesticated fauna and flora with important archaeological and sacred sites from Incan and pre-Incan times (CIP 2013; IBHC 2013).

\section{General discussion}

In this study, we have used Impact Assessment to describe the implications for adopting agrobiodiversity on a large scale. A new report from the United Nations Conference on Trade and Development (UNCTAD 2013) recommends a rapid shift away from "conventional, monoculture-based industrial 
production" of food that depends heavily on external inputs such as fertilizer, agro-chemicals and concentrate feed. Instead, it says that the goal should be "mosaics of sustainable regenerative production systems that also considerably improve the productivity of small-scale farmers and foster rural development". The report stresses that governments must find ways to factor in and reward farmers for currently unpaid public goods (ecosystem services) they provide, such as clean water, soil and landscape preservation, protection of biodiversity, and recreation. Data from the last 20 years show that the potential for increased production of minor crops is much greater than for the dominant major crops (Lobell and Field 2007). Several of the above mentioned minor crops have shown significant development in global production and trade from a local origin with domestic production (Fig. 3).

The production of yam-bean has more than tripled in the last 30 years, and the production of quinoa has nearly doubled since 1980. In comparison, a major crop like wheat has been reduced by $8 \%$ since 1980 despite the significant increase in global food production. A similar pattern is observed for rice and sorghum with reduced global production. Sorghum has in recent years been replaced by maize in many African countries, which may explain the slight decrease in sorghum production. The global production of maize, on the other hand, has increased significantly in the last decades (Fig. 2). Soybean production, mainly for protein feed, and its area have increased dramatically, mainly in vulnerable areas of Brazil and in China .

When considering global crop production (Goldschein 2011), new crops of potential for increased production should also be considered (Table 2). The present yield is based on statistics (quinoa), and our own estimates (amaranth, Andean lupin, yam bean, nopal and tsamma-watermelon). The yield potential is also estimated conservatively. We present this information as a basis for discussion and to demonstrate the potential of minor crops on a global scale.
Table 1 Most important crops with respect to production (Goldschein 2011), and several new crops with potential for increased production

\begin{tabular}{|c|c|c|c|c|c|c|c|}
\hline & \multirow[t]{2}{*}{ Crop } & \multicolumn{3}{|c|}{ Current production } & \multicolumn{3}{|c|}{ Potential of new crops } \\
\hline & & mill. $\mathrm{t}$ & $\mathrm{t} / \mathrm{ha}$ & mill. ha & mill. $\mathrm{t}$ & $\mathrm{t} / \mathrm{ha}$ & mill. ha \\
\hline \multicolumn{8}{|c|}{ Top 10 crops } \\
\hline 1 & Maize & 823 & 5.1 & 161 & & & \\
\hline 2 & Wheat & 690 & 3.1 & 223 & & & \\
\hline 3 & Rice & 685 & 4.3 & 159 & & & \\
\hline 4 & Potato & 314 & 17.2 & 18 & & & \\
\hline 5 & Manioc & 233 & 12.5 & 19 & & & \\
\hline 6 & Soybean & 231 & 2.4 & 96 & & & \\
\hline 7 & Sweet potato & 110 & 13.5 & 8 & & & \\
\hline 8 & Sorghum & 66 & 1.5 & 44 & & & \\
\hline 9 & Yam & 52 & 10.5 & 5 & & & \\
\hline 10 & Plantain & 34 & 6.3 & 5 & & & \\
\hline \multicolumn{8}{|c|}{ New crops } \\
\hline & Quinoa & 0.09 & 0.6 & 0.150 & 72 & 3 & 24 \\
\hline & Amaranth & 0.08 & 0.4 & 0.200 & 45 & 3 & 15 \\
\hline & Andean lupine & 0.01 & 0.5 & 0.020 & 20 & 4 & 5 \\
\hline & Yam bean & 0.10 & 1.0 & 0.004 & 200 & 70 & 15 \\
\hline & Nopal & 0.12 & 58.3 & 0.002 & 200 & 60 & 10 \\
\hline & Seed-watermelon & 0.6 & 0.4 & 0.600 & 45 & 3 & 5 \\
\hline
\end{tabular}

The present yields are based on statistics (quinoa), or our estimates (amaranth, Andean lupine and yam bean). The yield potentials are medium term and conservative estimates

For instance, we estimate that it is realistic to replace $10 \%$ of the rice and $5 \%$ of the maize area with quinoa, which will give a quinoa area of 24 million ha, from today's 150,000 ha. The potential within the next 10-20 years for amaranth, Andean lupine and yam bean is 15,5 and 10 million ha, respectively (Table 1).

We have estimated which major crops may be replaced by the new crops in the production and as food sources, and to
Fig. 3 Development in global production of selected crops. $1980=$ index 100, Own calculations based on FAO statistics (FAO 2010)

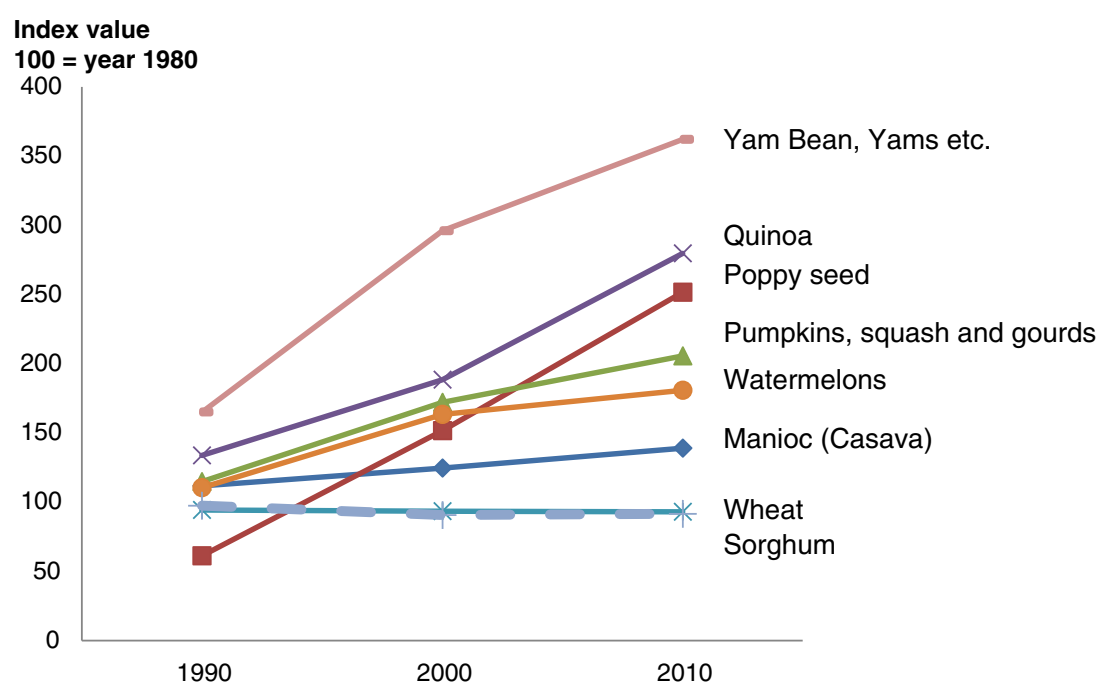


Table 2 Quantitative comparisons between a few lesser-known species in terms of their nutritive value or potential in terms of reachable population numbers, or compatibility with existing farming systems, etc., would be extremely useful

\begin{tabular}{|c|c|c|c|}
\hline New crop & Replacing major crops & Replacing major food & Adapted to climatic conditions \\
\hline Quinoa & Maize, wheat, barley & Rice, wheat, maize & $\begin{array}{l}\text { Temperate to subtropics, max. } 35^{\circ} \mathrm{C} \text {. Sandy soils, } \\
\text { dryland ( }>200 \text {-mm precipitation), saline soils }\end{array}$ \\
\hline Amaranth & Maize, wheat & Rice, wheat, maize, sorghum, & $\begin{array}{l}\text { Temperate to tropics, high temperatures. Some } \\
\text { tolerance to drought and soil salinity }\end{array}$ \\
\hline Andean lupine & Soybean, faba bean & Soybean and other legumes & $\begin{array}{l}\text { Relative good soils, temperate to subtropics. } \\
\text { N fixing }\end{array}$ \\
\hline Yam bean & Maize, manioc & Roots and tubers & Tropics-subtropics \\
\hline Nopal & Desert plants & Vegetables & Extreme dry land \\
\hline Seed-watermelon & Desert plants & Vegetables & Dryland \\
\hline
\end{tabular}

which climatic conditions they are adapted (Table 2). The conservative estimates given by the authors are based on yields from not published field trials performed at local experimental stations.

The new crops are alternatives to several of the most important crops, with better tolerance to abiotic adverse factors in general.

Other crops such as pumpkins and squash are used as fodder and food as well as cultural purposes (e.g. pumpkins for Halloween) with increased production all over the world. Besides producing illegal drugs, a crop like poppy (Papaver somniferum L.), both blue and white, is a highly nutritious food consumed in many parts of the world. The mature poppy seeds are eaten with pasta or milk or used as topping on various kinds of pastry and cakes. Currently, Turkey and Tasmania each produces about one third of the global production of poppy seed (Turquisefoods 2009).

Manioc is a root crop of South American origin mainly produced in Africa and South America, but also in Asia (Thailand and Indonesia). Manioc grown for food is mainly produced for home consumption, but the crop is widely cultivated for the production of dried chips for fodder and for starch extraction.

Increased global trade, reduced cost of freight and new storage methods have enabled consumers to purchase crops that are not produced domestically. Modern consumers seek a diet with a variety of ingredients from different origins.

\section{Conclusion}

There is a great need for scientific research in agrobiodiversity solutions to increase good quality food production, and this area has not been given sufficient attention within scientific research community. Advocates of GMO and other high-tech solutions to increase food production focus on nutritionally improved GMO varieties of major cereals, such as Golden Rice, roots and pulses (Blanchfield 2004; Schiøler 2013) or novel GMO traits for improved pest and disease tolerance (Jones and Hockridge 2011). But, nutritionists, human ecologists and many consumers see an approach based on dietary variation and environmental sustainability from existing agrobiodiversity as more appropriate. There is a wide range of existing and emerging problems related to food security that can be tackled by optimizing crop management (FAOSTAT 2012). Key areas include pest and disease control, use of salt and drought-tolerant crops and cultivars, improved crop yield and quality, and strengthening the sustainability and environmental impact of crop production. The knowledge gained from basic plant research will underpin future crop improvements, although effective mechanisms for the rapid and effective translation of research discoveries into publicgood agriculture remain to be developed. Maximum benefit will be derived if robust plant breeding and crop management programmes have ready access to modern technologies to address food security issues. This will require additional investments in capacity building for research and development in developing countries. Technology implementation alone is not sufficient to address such complex questions as food security.

Good nutrition depends on adequate intakes of a range of nutrients and other compounds. The best way to eliminate undernutrition worldwide is to provide increased local production and consumption of a range of non-staple foods and underutilized species.

Diversified agricultural systems not only render smallholder farming more sustainable, they also reduce the vulnerability of poor farmers. Such systems minimize the risk of harvest failures caused by droughts or floods, extremes of temperature and outbreaks of pests and diseases, which will be exacerbated by climate change (Schmidhuber and Tubiello 2007). Rather, the available evidence supports a focus on agrobiodiversity as the most appropriate technology to secure food production in sufficient quantities and high quality in the years to come through (1) improved agricultural practices in hunger-prone developing countries, (2) development of agrobiodiversity resources through plant breeding, and (3) improved, diverse 
consumption lower on the food chain and focused on highvalue plant products.

Open Access This article is distributed under the terms of the Creative Commons Attribution 4.0 International License (http:// creativecommons.org/licenses/by/4.0/), which permits unrestricted use, distribution, and reproduction in any medium, provided you give appropriate credit to the original author(s) and the source, provide a link to the Creative Commons license, and indicate if changes were made.

\section{References}

Acton DF, Gregorich LJ (eds) (1995) The health of our soils - towards sustainable agriculture in Canada. Centre for Land and Biological Resources Research, Research Branch, Agriculture and Agri-Food Canada, Ottawa. xiv + pp 138, http://agrienvarchive.ca/bioenergy/ download/Health_of_Our_Soils.pdf. Accessed 17 Feb 2013

Adolf VI, Jacobsen S-E, Shabala S (2013) Salt tolerance mechanisms in quinoa (Chenopodium quinoa Willd.). Environ Exp Bot 92:43-54. doi:10.1016/j.envexpbot.2012.07.004

Ahmad SS, Javed S (2007) Exploring the economic value of underutilized plant species in Ayubia National Park. Pak J Bot 39(5):1435-1442

Aker JC (2011) Dial "A" for agriculture: a review of information and communication technologies for agricultural extension in developing countries. Tufts University, Economics Department and Fletcher School, Medford, p 37

Alnwick D (1996) Significance of micronutrient deficiencies in developing and industrialized countries. In: Combs GF, Welch RM, Duxbury JM, Uphoff NT, Nesheim MC (eds) Food-based approaches to preventing micronutrient malnutrition. An International Research Agenda. Cornell University, Ithaca, p 68

Amaranthus M, Anderson J, Marler J (2009) Degraded soils and food shortages: organic and biological agricultura strategies are needed now. Nutrition Security Institute. http://www.nutritionsecurity.org/ PDF/DegradedSoils.pdf. Accessed 17 Feb 2013

Andika DO, Onyango MOA, Onyago JC (2008) Role of Bambara groundnut (Vigna subterranea) in cropping systems in Western Kenya. In: Smartt J, Haq N (eds) 5th International Symposium on New Crops and Uses: their role in a rapidly changing world, University of Southampton, Southampton, UK, 3-4 September 2007. Centre for Underutilized Crops. University of Southampton, Southampton, pp 204-212

Baena M, Galluzzi G, Padulosi S (2012) Improving community livelihoods by recovering and developing their traditional crops. Policy brief. Bioversity International. pp 4, http://www. bioversityinternational.org/fileadmin/user_upload/online_library/ publications/pdfs/1570.pdf. Accessed 20 Aug 2014

Bala Raví S (2004) Neglected millets that save the poor from starvation. LEISA India 6(1):34-36, http://www.agriculturesnetwork.org/ magazines/india/1-valuing-crop-diversity/neglected-millets-thatsave-the-poor-from/at_download/article_pdf. Acessed 17 Feb 2013

Bazile D, Bertero D, Nieto C (eds) (2013) Estado del arte de la quinua en el mundo en 2013: Libro de resúmenes. Publication from FAO/ CIRAD due to the International Quinoa Year 2013. Pp 733. http:// www.fao.org/3/a-i4042s.pdf. Accessed 20 Aug 2014

Blanchfield JR (2004) Genetically modified food crops and their contribution to human nutrition and food quality. J Food Sci 69(1): CRH28-CRH30. doi:10.1111/j.1365-2621.2004.tb17846.x

Bond A, Pope J (2012) The state of the art of impact assessment in 2012. Impact Assess Proj Appraisal 30:1-4. doi:10.1080/14615517.2012. 669140
Brändli D, Reinacher S (2012) Herbicides found in human urine. Ithaka J 1:270-272 ISSN 1663-0521. http://www.ithaka-journal.net/ druckversionen/e052012-herbicides-urine.pdf. Accessed 20 Aug 2014

Brun T, Reynaud J, Chevassus-Agnes S (1989) Food and nutritional impact of one home garden project in Senegal. Ecol Food Nutr 23: 91-108. doi:10.1080/03670244.1989.9991092

Buffin D, Jewell T (2001) Health and environmental impacts of glyphosate: the implications of increased use of glyphosate in association with genetically modified crops. In: Riley $\mathrm{P}$, Taylor $\mathrm{M}$, Diamand E, Barron H (eds) foe.co.uk. http://www.foe.co.uk/ sites/default/files/downloads/impacts_glyphosate.pdf. Accessed 25 Mar 2013

Bullock JM, Pywell RF, Walker KJ (2007) Long-term enhancement of agricultural production by restoration of biodiversity. J Appl Ecol 44:6-12. doi:10.1111/j.1365-2664.2006.01252.x

Burke M, Lobell D, Guarino L (2009) Shifts in African crop climates by 2050, and the implications for crop improvement and genetic resources conservation. Glob Environ Chang 19:317-325. doi:10. 1016/j.gloenvcha.2009.04.003

Businessballs (2014) http://www.businessballs.com/ swotanalysisfreetemplate.htm. Accessed 24 April 2014

Cerdeira AL, Gazziero DLP, Duke SO, Matallo MB, Spadotto CA (2007) Review of potential environmental impacts of transgenic glyphosate-resistant soybean in Brazil. J Environ Sci Health B 42: 539-549. doi:10.1080/03601230701391542

CGIAR (2010) The second report on the state of the world's plant genetic resources for food and agriculture. Rome: http://www.fao.org/ docrep/013/i1500e/i1500e_brief.pdf. Accessed 25 March 2013

CIP [International Potato Center] (2013) Potato Park. http://cipotato.org/ genebank/potato-park. Accessed 17 Feb 2013

Collinson ST, Azam-AIi SN, Chavula KM, Hodson OA (1996) Growth development and yield of Bambara groundnut (Vigna subterranea) in response to soil moisture. J Agric Sci 126:307-318. doi:10.1016/ j.eja.2006.09.007

Conner AJ, Mercer CF (2007) Breeding for success: diversity in action. Euphytica 154:261-262. doi:10.1007/s10681-006-9341-y

Connor DJ, Loomis RS, Cassman KG (2011) Crop ecology-productivity and management in agricultural systems, 2nd edn. Cambridge University Press, Cambridge, p 562

de Benoist B, McLean E, Egli I, Cogswell M (eds) (2008) Worldwide prevalence of anaemia 1993-2005: WHO global database on anaemia. WHO, Geneva. http://whqlibdoc.who.int/publications/2008/ 9789241596657 eng.pdf. Accessed 25 March 2013

De Schutter O (2011) Agroecology and the right to food. Report presented at the 16th session of the United Nations Human Rights Council [A/HRC/16/49] http://www.srfood.org/images/stories/pdf/ officialreports/20110308_a-hrc-16-49_agroecology_en.pdf. Accessed 25 March 2013

DeFelice MS (2004) Prickly pear cactus, Opuntia spp.- - a spine-tingling tale. Weed Technol 18:869-877. doi:10.1614/WT-04-134

Dyson RG (2004) Strategic development and SWOT analysis at the University of Warwick. Eur J Oper Res 152(3):631-640. doi:10. 1016/S0377-2217(03)00062-6

Eyzaguirre PB, Linares OF (2004) Home gardens and agrobiodiversity. Smithsonian Books, Washington, DC

FAO (1983) FAO Soils Bulletin. 50. http://www.fao.org/docrep/T0389E/ T0389E02.htm. Accessed 17 Feb 2013

FAO (1990) Biological diversity. Its conservation and use for sustainable agricultural, forestry and fisheries development. FAO Working Paper, pp 41, http://www.bmel.de/SharedDocs/Downloads/EN/ Publications/AgriculturalBiodiversity.pdf? blob=publicationFile. Accessed 17 Feb 2013

FAO (1997) Chapter 5 - promotion of food and dietary diversification strategies to enhance and sustain household food security. In: Agriculture food and nutrition for Africa - a resource book for 
teachers of agriculture. Food and Nutrition Division, FAO, Rome, 1997. http://www.fao.org/docrep/w0078e/w0078e06.htm. Accessed 25 March 2013

FAO (2004) What is agrobiodiversity? In: Building on gender, agrobiodiversity and local knowledge. FAO, 2004. ftp://ftp.fao. org/docrep/fao/007/y5609e/y5609e00.pdf. Accessed 20 Aug 2014

FAO (2010) The state of food insecurity in the world - addressing food insecurity in protracted crises. FAO, Rome, pp. 62. http://www.fao. org/docrep/013/i1683e/i1683e.pdf. Accessed 25 March 2013

FAO (2013a) 2013 International Year of Quinoa. http://www.fao.org/ quinoa-2013/en/. Accessed 20 Aug 2014

FAO (2013b) Food Outlook - Biannual report on global food markets. pp 140, http://www.fao.org/3/a-i4136e.pdf. Accessed 20 Aug 2014

FAOSTAT (2012) Statistics at FAO-The Food and Agriculture Organization of the United Nations. http://www.fao.org/statistics/ en/. Accessed 25 March 2013

Faville MJ, Richardson K, Mace W, Sun XZ, Harrison S, Knapp K, Jahufer MZZ, Palanisamy R, Pirlo S, Johson RR, Rasmussen S, Bryan G (2010) Genetic improvement of fibre tracts in perennial ryegrass. Proc N Z Grassl Assoc 72:71-78, http://www.grassland. org.nz/publications/nzgrassland publication 25.pdf. Accessed 25 March 2013

Feder G, Just RE, Zilberman D (1985) Adoption of agricultural innovations in developing countries: a survey. Econ Dev Cult Chang 33(2): 255-298, http://www-wds.worldbank.org/servlet/ WDSContentServer/IW3P/IB/2003/07/26/000178830 9810190341413/Rendered/PDF/multi0page.pdf. Accessed 20 Aug 2014

Frison E, Cherfas J, Hodgkin T (2011) Agricultural biodiversity is essential for a sustainable improvement in food and nutrition security. Sustainability 3(1):238-253. doi:10.3390/su3010238

Gallin D (2001) Propositions on trade unions and informal employment in times of globalisation. Blackwell Publishers, Antipode, pp 531549. http://www.inclusivecities.org/wp-content/uploads/2012/07/ Gallin_GLI_Propositions_Trade_Unions_IE.pdf. Accessed 20 Aug 2014

Galluzzi G, Eyzaguirre P, Negri V (2010) Home gardens: neglected hotspots of agrobiodiversity and cultural diversity. Biodivers Conserv 19:3635-3654. doi:10.1007/s10531-010-9919-5

Goldschein E (2011) The 10 most important crops in the World. http:// www.businessinsider.com/10-crops-that-feed-the-world-2011-9? op=1\#ixzz3F4FxhHJQ. Accessed 25 March 2013

Grum M (2009) Threats to biodiversity. In: Rudebjer P, Van Schlagen B, Chakeredza S, Karnau H (eds) Proc. learning agrobiodiversity: options for universities in Sub-Saharan Africa, 21-23 January 2009, Nairobi, Kenya, pp 78-80, http://www.google.dk/url?sa=t\&rct= $\mathrm{j} \& \mathrm{q}=\&$ esrc $=\mathrm{s} \&$ source $=$ web $\& \mathrm{~cd}=1 \& \mathrm{ved}=0$ CCEQFjAA\&url $=$ http $\% 3 \mathrm{~A} \% 2 \mathrm{~F} \% 2 \mathrm{Fknowledge}$.cta.int $\% 2 \mathrm{Fcontent} \% 2 \mathrm{Fdownload} \%$ 2F $23104 \% 2$ F $294607 \% 2$ Ffile $\% 2$ F $09 \quad 35 \% 2$ BCDU\% 2 B p r o c e e d ing s W E B.pdf \& e i $=$ O g a J V d 4JcG3sQGVoJvYBg\&usg=AFQjCNGQ1ygiEVsCPRAkqRt4efUqdTO8w\&bvm=bv.96339352,d.bGg\&cad=rja. Accessed 17 Feb 2013

Hall E, Hurst A (2012) Seasonal production of Coloured Brome (Bromus coloratus Steud.) cv. Exceltas, a new high quality temperate pasture grass. Proceedings of the 16th Australian Agronomy Conference 2012, 14-18 October 2012, University of New England, Armidale, NSW (In Press) [Refereed Conference Paper]. http:// www.regional.org.au/au/asa/2012/pastures/7932_hallej.htm. Accessed 25 March 2013

Halloy SRP, Ortega R, Yager K, Seimon A (2005) Traditional Andean cultivation systems and implications for sustainable land use. Acta Horticult 670:31-55, http://www.actahort.org/members/showpdf? session=19889. Accessed 20 Aug 2014

Hawtin G (2007). Underutilized plant species research and development activities - review of issues and options. http://www.fao.org/docs/
eims/upload/232403/Hawtin_REPORT_GFU-ICUC.pdf. pp 78. Accessed 25 March 2013

Hegde NG (2009) Promotion of underutilízed crops for income generation and environmental sustainability. Acta Horticult 806:563-577, http://www.actahort.org/books/806/806 70.htm. Accessed 25 March 2013

Heller J (1996) Physic nut. Promotion, conservation and use of underutilized neglected crops 1. [Series foreword]. IPGRI, Rome, p 5, http://www6.zetatalk.com/docs/Crops/Promoting_Use Of Underutilized_And_Neglected_Crops_1_Physic_Jatropha_Nut_ 1996.pdf. Accessed 17 Feb 2013

Heller J, Begemann F, Mushonga LJ (eds) (1997) Promotion, conservation and use of underutilized neglected crops. Bambara groundnut. Proceedings of the workshop on conservation and improvement of Bambara groundnut, 14-16 November 1995, Harare, Zimbabwe. IPGRI Promoting the conservation and use of underutilized and neglected crops. 9:1-173. http://pdf.usaid.gov/pdf_docs/pnach877. pdf. Accessed 17 Feb 2013

Huang J, Pray C, Rozelle S (2002) Enhancing the crops to feed the poor. Nature 418:678-684. doi:10.1038/nature01015

IBHC [Indigenous Biocultural Heritage] (2013) Association of communities of Potato Park http://www.parquedelapapa.org/eng/02somos 01.html. Accessed $17 \mathrm{Feb} 2013$

ISAAA.ORG [The International Service for the Acquisition of Agribiotech Applications] (2013) GM crops: a story in numbers. Nature 497(7447):22-23. doi:10.1038/497022a

Isenring, R (2010) Pesticides reduce Biodiversity. Pestic News 88:4-7, http://www.pan-uk.org/pestnews/Issue/pn88/PN88_p4-7.pdf. Accessed 17 Feb 2013

ISF [International Seed Federation] (2011) Agriculture under pressure. http://www.worldseed.org/isf/home.html. Accessed 17 Feb 2013

Jackson SE, Joshi A, Erhardt NL (2003) Recent research on team and organizational diversity: SWOT analysis and implications. J Manag 29(6):801-830

Jacobsen S-E (1997) Adaptation of quinoa (Chenopodium quinoa) to Northern European agriculture: studies on developmental pattern. Euphytica 96:41-48, http://link.springer.com/content/ pdf/10.1023\%2FA\%3A1002992718009.pdf. Accessed 17 Feb 2013

Jacobsen S-E (2003) The worldwide potential for quinoa (Chenopodium quinoa Willd.). Food Rev Int 19:167-177. http://quinua.pe/wpcontent/uploads/2013/02/sven-erik.pdf. Accessed 17 Feb 2013

Jacobsen S-E (2011) The situation for Quinoa and its production in Southern Bolivia: from economic success to environmental disaster. J Agron Crop Sci 197:390-399. doi:10.1111/j.1439-037X.2011. 00475.x

Jacobsen S-E (2012) What is wrong with the sustainability of Quinoa production in Southern Bolivia- a reply to Winkel et al. (2012). J Agron Crop Sci 198:320-323. doi:10.1111/j.1439-037X.2012. 00511.x

Jacobsen S-E, Jørgensen I, Stølen O (1994) Cultivation of quinoa (Chenopodium quinoa) under temperate climatic conditions in Denmark. J Agric Sci 122:47-52. doi:10.1017/ S0021859600065783

Jacobsen S-E, Hill J, Stølen O (1996) Stability of quantitative traits in quinoa (Chenopodium quinoa). Theor Appl Genet 93:110-116. doi: 10.1007/BF00225735

Jacobsen S-E, Mujica A, Jensen CR (2003a) The resistance of quinoa (Chenopodium quinoa Willd.) to adverse abiotic factors. Food Rev Int 19:99-109. doi:10.1081/FRI-120018872

Jacobsen S-E, Mujica A, Ortiz R (2003b) The global potential for quinoa and other Andean crops. Food Rev Int 19:139-148. doi:10.1081/ FRI-120018880

Jacobsen S-E, Monteros C, Christiansen JL, Bravo LA, Corcuera LJ, Mujica A (2005) Plant responses of quinoa (Chenopodium quinoa 
Willd.) to frost at various phenological stages. Eur J Agron 22:131139. doi:10.1016/j.eja.2004.01.003

Jacobsen S-E, Monteros C, Corcuera LJ, Bravo LA, Christiansen JL, Mujica A (2007) Frost resistance mechanisms in quinoa (Chenopodium quinoa Willd.). Eur J Agron 26:471-475. doi:10. 1016/j.eja.2007.01.006

Jacobsen S-E, Christiansen JL, Rasmussen J (2010) Weed harrowing and inter-row hoeing in organic grown quinoa (Chenopodium quinoa Willd.). Outlook Agric 39:223-227. doi:10.5367/oa.2010.0001

Jacobsen S-E, Jensen CR, Liu F (2012) Improving crop production in the arid Mediterranean climate. Field Crops Res 128:34-47. doi:10. 1016/j.fcr.2011.12.001

Jacobsen S-E, Sørensen M, Pedersen SM, Weiner J (2013) Feeding the world: genetically modified crops versus agrobiodiversity. Agron Sustain Dev 33:651-662. doi:10.1007/s13593-013-0138-9

Jensen BD, Christiansen JL, Andersen SB (2009) Vandmeloner i Saharas sand - genetiske ressourcer for fremtiden. Faculty of life Sciences, University of Copenhagen, Temahæfte 2009. Ulande naturressourcer, fødevarer og sundhed, pp 10-11, http://www.epages.dk/ku/197/4. Accessed 17 Feb 2013

Jones J, Hockridge E (2011) GM Foods - feeding the world or destroying the planet? Speakers Corner Trust. http://www.speakerscornertrust. org $/ 5359 / \mathrm{gm}$-foods- $\% \mathrm{E} 2 \% 80 \% 93$-feeding-the-world-ordestroying-the-planet/. Accessed 17 Feb 2013

Jones RB, Rakotoarisaona JJ (2007) Supporting the development of sustainable seed systems for non-hybrid crops. Acta Horticult 752:7782. http://www.actahort.org/books/752/752_8.htm. Accessed 20 Aug 2014

Juma C (2011) The new harvest - agricultural innovations in Africa. Oxford University Press, Inc., Oxford, p 296

Kahane R, Hodgkin T, Jaenicke H, Hoogendoorn C, Hermann M, Keatinge JDH, d'Arros J (2013) Agrobiodiversity for food security, health and income. Agron Sustain Dev 33:671-693. doi:10.1007/ s13593-013-0147-8

Ladizinsky G (1998) Plant evolution under domestication. Kluwer Academic Publishers, The Netherlands. doi:10.1007\%2F978-94$011-4429-2$

Lal R (2008) Soils and sustainable agriculture. A review. Agron Sustain Dev 28:57-64. doi:10.1051/agro:2007025

Lamien N, Traore-Gue J, Linganl-Coulibaly P (2009) Importance of local fruits consumption in diet balance in Burkina Faso, West Africa. Acta Horticult 806:203-208, http://www.actahort.org/members/ showpdf? session=26710. Accessed 17 Feb 2013

Learned EP, Christensen CR, Andrews KE, Guth WD (1965) Business policy: text and cases. Irwin, Homewood, p 1046

Lichtfouse E, Navarrete M, Debaeke P, Souchere V, Alberola C, Menassieu J (2009) Agronomy for sustainable agriculture. A review. Agron Sustain Dev 29:1-6. doi:10.1051/agro:2008054

Lobell DB, Field CB (2007) Global scale climate-crop yield relationships and the impacts of recent warming. Environ Res Lett 2:1-7. doi:10. 1088/1748-9326/2/1/014002

Lopez-Noriega I, Galluzzi G, Halewood M, Vernooy R, Bertacchini E, Gauchan D, Welch E (2012) Flows under stress: availability of plant genetic resources in times of climate and policy change. CGIAR Research Program on Climate Change, Agriculture and Food Security (CCAFS) Working Paper 18. Copenhagen: CGIAR. http://hdl.handle.net/10568/21225. Accessed 17 Feb 2013

Lyimo M, Temu RPC, Mugula IK (2003) ldentification and nutrient composition of indigenous vegetables of Tanzania. Plant Food Hum Nutr 58:85-92, http://link.springer.com/content/pdf/10.1023\% 2FA\%3A1024044831196.pdf. Accessed 25 March 2013

Makoni N, Mohamed-Katerere J, Chenje M (2012) Genetically modified crops in: Africa Environment Outlook 2-our environment, our wealth, UNEP, pp 300-330, http://www.unep.org/DEWA/Africa/ docs/en/AEO2 Our Environ Our Wealth.pdf. Accessed 17 Feb 2013
Mayes S, Massawe FJ, Alderson PG, Roberts JA, Azam-Ali SN, Hermann M (2012) The potential for underutilized crops to improve security of food production. J Exp Bot 63:1075-1079. doi:10.1093/ jxb/err396

Mba C, Guimaraes EP, Ghosh K (2012) Re-orienting crop improvement for the changing climatic conditions of the 21 st century. Agricult Food Secur 2012, 1:7, http://www.agricultureandfoodsecurity.com/ content/1/1/7. Accessed 17 Feb 2013

Msuya JM, Mamiro P, Weinberger K (2009) Iron, zinc and pcarotene nutrient potential of noncultivated indigenous vegetables in Tanzania. Acta Horticult 806:217-222, http://www. actahort.org $/ \mathrm{members} /$ showpdf? session $=31458$. Accessed 25 March 2013

Mujica A, Jacobsen S-E (2003) The genetic resources of Andean grain amaranths (Amaranthus caudatus L., A. cruentus L. and A. hypochondriacus L.) in America. Plant Genet Res Newsl 133: 41-44, http://www.bioversityinternational.org/fileadmin/PGR/ article-issue 133-art 102-lang en.html. Accessed 25 March 2013

Murphy DJ (2007) Agricultural improvement in modern times. Oxford Sch Online. doi:10.1093/acprof:oso/9780199207145.003.0016

Musgrave DJ, Daly MJ (2004) Assessment of the performance of nonryegrass pasture mixtures. Proc N Z Grassl Assoc 66:279-282, http://www.grassland.org.nz/publications/nzgrassland_publication_ 449.pdf. Accessed 25 March 2013

Nair PKR (2001) Do tropical homegardens elude science, or is it the other way around? Agroforest Syst 53:239-245, http://link.springer.com/ content/pdf/10.1023\%2FA\%3A1013388806993.pdf. Accessed 25 March 2013

Ogle BM, Grivetti LE (1985) Legacy of the chameleon: edible wild plants in the Kingdom of Swaziland, southern Africa. A cultural, ecological, nutritional study. Demographics, species availability and dietary use, analysis by ecological zone. Ecol Food Nutr 17(1):1-30. doi:10. 1080/03670244.1985.9990879

Oré Balbin I, Sørensen M, Kvist LP, Delgado Vasquez O (2007) Review of the Pachyrhizus tuberosus (Lam.) Spreng. Cultivar groups in Peru. Plant Genet Res Newsl 151:1-11, http://www. bioversityinternational.org/fileadmin/PGR/article-issue_151-art_2lang_en.html. Accessed 25 March 2013

Pachauri RK, Reisinger A (eds) (2007) Climate change 2007: synthesis report, contribution of working groups I, II and III to the fourth assessment report of the Intergovernmental Panel on Climate Change. IPCC, Geneva, Switzerland, p. 104, https://www.ipcc.ch/ pdf/assessment-report/ar4/syr/ar4_syr_full_report.pdf. Accessed 17 Feb 2013

Padulosi S, Hodgkin T, Williams JT, Haq N (2006) Underutilized crops: trends, challenges and opportunities in the 21st Century. Moringa and other highly nutritious plant resources: Strategies, standards and markets for a better impact on nutrition in Africa. Accra, Ghana, November 16-18, 2006, http://www.moringanews.org/doc/GB/ GFU/Document8.pdf. Accessed 17 Feb 2013, pp 23

Padulosi S, Heywood V, Hunter D, Jarvis A (2011) Underutilized species and climate change: current status and outlook. In: Yadav SS, Redden RJ, Hatfield JL, Lotze-Campen H, Hall AE (eds) Crop Adaptation to Climate Change, 1st edn, John Wiley \& Sons, Ltd., Blackwell Publishing Ltd., pp 507-521, doi: 10.1002/ 9780470960929.ch35

Parry M, Evans PM, Rosegrant W, Wheeler T (2009) Climate change and hunger: responding to the challenge. World Food Programme, Rome, p. 108, http://documents.wfp.org/stellent/groups/public/ documents/newsroom/wfp212536.pdf. Accessed 17 Feb 2013

Pedersen SM (2003) Precision farming - Technology assessment of sitespecific input application in cereals, Department of Manufacturing Engineering and Management, Technical University of Denmark. $\mathrm{PhD}$ dissertation, pp 343

Perez C, Nicklin C, Dangles O, Vanek S, Sherwood S, Halloy S, Garrett K, Forbes G (2010) Climate change in the high Andes: implications 
and adaptation strategies for small-scale farmers. Int $\mathrm{J}$ Environ Cult Econ Soc Sustain 6(5):71-88. http://dangles.naturexpose.com/IMG/ file/pdf\%20peer-reviewed/2010_perez_et_al.pdf. Accessed 25 March 2013

Pope J, Bond A, Morrison-Saunders A, Retief F (2013) Advancing the theory and practice of impact assessment: setting the research agenda. Environ Impact Assess Rev 41:1-9. doi:10.1016/j.eiar.2013.01. 008

Porter JR, Challinor A, Ewert F, Falloon P, Fischer T, Gregory P, Van Ittersum MK, Olesen JE, Moore KJ, Rosenzweig C, Smith P (2010) Food security: focus on agriculture. Science 328:172-173. doi:10. 1126/science.328.5975.172

Poulton C, Dorward A, Kydd J (2010) The future of small farms: new directions for services, institutions, and intermediation. World Dev 38(10):1413-1428. doi:10.1016/j.worlddev.2009.06.009

Rastogi A, Shukla S (2013) Amaranth: a new millennium crop of nutraceutical values. Crit Rev Food Sci 53:109-125. doi:10.1080/ 10408398.2010.517876

Razzaghi F, Ahmadi SH, Adolf VI, Jensen CR, Jacobsen S-E, Andersen MN (2011) Water relations and transpiration of Quinoa (Chenopodium quinoa Willd.) under salinity and soil drying. J Agron Crop Sci 197:348-360. doi:10.1111/j.1439-037X.2011. 00473.x

Razzaghi F, Ahmadi SH, Jacobsen S-E, Jensen CR, Andersen MN (2012) Effects of salinity and soil-drying on radiation use efficiency, water productivity and yield of Quinoa (Chenopodium quinoa Willd.). J Agron Crop Sci 198:173-184. doi:10.1111/j.1439-037X.2011. 00496.x

Repo-Carrasco R, Espinoza C, Jacobsen S-E (2003) Nutritional value and use of the Andean crops quinoa (Chenopodium quinoa) and kañiwa (Chenopodium pallidicaule). Food Rev Int 19(1-2):179-189, http:// www.infoandina.org/sites/default/files/publication/files/ FoodreviewRitva.pdf. Accessed 25 March 2013

Robles-Contreras F, Macías-Duarte R, Grijalva-Contreras RL (2008) Tecnología de producción de nopal verdura para el noroeste de Sonora. Instituto Nacional de Investigaciones Forestales, Agrícolas y Pecuarias [INIFAP] Folleto Técnico, pp 28. http://biblioteca. inifap.gob.mx:8080/jspui/bitstream/handle/123456789/1615/ Tecnologia $\% 20$ de $\% 20$ produccion $\% 20$ de $\% 20$ nopal $\% 20$ verdura $\%$ 20 para $\% 20$ el $\% 20$ noroeste $\% 20 \mathrm{de} \% 20$ Sonora.pdf? sequence $=1$. Accessed 20 Aug 2014

Rojas W, Soto J, Pinto M, Jager M, Padulosi S (2010) Granos andinos: avances, logros y experiencias desarrolladas en quinua, cañahua y amaranto en Bolivia. Rome, Italy: Bioversity International. p. 191, http://www.bioversityinternational.org/uploads/tx news/Granos andinos_avances_logros_y_experiencias_desarrolladas_en quinua_cañahua_y_amaranto_en_Bolivia_1413.pdf. Accessed $1 \overline{7}$ Feb $20 \overline{13}$

Rudebjer P (2009) Agrobiodiversity in food systems, ecosystems and education systems. In: Rudebjer P, Van Schlagen B, Chakeredza S, Karnau H (eds) Proc. Learning agrobiodiversity: options for universities in Sub-Saharan Africa, 21-23 January 2009, Nairobi, Kenya, pp 28-33, http://www.google.dk/url? sa=t\&rct=j\&q=\&esrc= s\&source=web\&cd $=1 \&$ ved $=0$ CCEQFjAA\&url $=\mathrm{http} \% 3 \mathrm{~A} \% 2 \mathrm{~F} \%$ 2Fknowledge.cta.int $\% 2 \mathrm{Fcontent} \% 2 \mathrm{Fdownload} \% 2 \mathrm{~F} 23104 \%$ 2F294607\%2Ffile\%2F09 35\%2BCDU\%2Bproceedings WEB. p d f \& e i $=$ O g a J V d - 4 J c G 3 s Q G Vo J v Y B g \& u s g = AFQjCNGQ1ygiEVsCPRAkqRt4-efUqdTO8w\&bvm=bv. 96339352,d.bGg\&cad=rja. Accessed 17 Feb 2013

Rudebjer P, van Schagen B, Chakeredza S, Njoroge K, Kamau H, Baena M (2011) Teaching agrobiodiversity: a curriculum guide for higher education. Bioversity International, Rome, p. 96, http://www. bioversityinternational.org/fileadmin/_migrated/uploads/tx_news/ Teaching_agrobiodiversity_a_curriculum_guide_for_higher education_1495.pdf. Accessed $1 \overline{7}$ Feb 2013
Salinger G (2012) Five agricultural innovations to improve biodiversity. http://blogs.worldwatch.org/nourishingtheplanet/five-agriculturalinnovations-to-improve-biodiversity/. Accessed 17 Feb 2013

Sanchís J, Kantiani L, Llorca M, Rubio F, Ginebreda A, Fraile J, Garrido T, Farré M (2012) Determination of glyphosate in groundwater samples using an ultrasensitive immunoassay and confirmation by online solid-phase extraction followed by liquid chromatography coupled to tandem mass spectrometry. Anal Bioanal Chem 402(7): 2335-2345. doi:10.1007/s00216-011-5541-y, Epub 2011 Nov 20

Schiøler E (2013) Den skjulte sult og forædlede afgrøder. Information 19 Feb 2013, http://www.information.dk/451581

Schmidhuber J, Tubiello F (2007) Global food security under climate change. PNAS 104(50):19703-19708. doi:10.1073/pnas. 0701976104

Shackleton CM, Pasquini MW, Dresche AW (2009) African indigenous vegetables in urban agriculture. Earthscan, London, UK, Sterling, VA, USA, pp 339, http://www.actuar-acd.org/uploads/5/6/8/7/ 5687387/african_indigenous_vegetables_in_urban_agriculture earthscan_2009.pdf. Accessed 17 Feb $201 \overline{3}$

Smith FI, Eyzaguirre P (2007) African leafy vegetables: their role in the World Health Organization's global fruit and vegetables initiative. Afr J Food Agric Nutr Dev 7(3):1-17, http://www.bioline.org.br/ request?nd07019. Accessed 17 Feb 2013

Sørensen M (1996) Yam bean (Pachyrhizus DC.). Promoting the conservation and use of underutilized and neglected crops. 2 (Heller, J. series ed.) Institute of Plant Genetics and Crop Plant Research, Gatersleben / International Plant Genetic Resources Institute, Rome, pp 141, http://www.bioversityinternational.org/uploads/tx news/Yam_bean_Pachyrhizus_DC._311.pdf. Accessed $2 \overline{5}$ March 2013

Sørensen M (2004) Supercrop - the yam bean. Nat Hist Mag 113(3):38 43, ISSN: 0028-0712

Sørensen M, Døygaard S, Estrella E, Kvist LP, Nielsen PE (1997a) Status of the South American tuberous legume Pachyrhizus tuberosus (Lam.) Spreng. Biodivers Conserv 6(12):1581-1625, http://link. springer.com/content/pdf/10.1023\%2FA\%3A1018326805849.pdf. Accessed 25 March 2013

Sørensen M, Grüneberg WJ, Ørting B (1997b) Ahipa (Pachyrhizus ahipa (Wedd.) Parodi). In: Hermann M, Heller J (eds). Andean roots and tubers. Promoting the conservation and use of underutilized and neglected crops. 21. Institute of Plant Genetics and Crop Plant Research, Gatersleben/International Plant Genetic Resources Institute, Rome, pp 13-73, http://www.bioversityinternational.org/ uploads/tx_news/Andean_roots and tubers 472.pdf. Accessed 25 March $201 \overline{3}$

Souza JD, Kulkarni AR (1993) Comparative studies on nutritive values of tender foliage of seedlings and mature plants of Moringa oleifera Lam. J Econ Taxon Bot 17:479-785. doi:10.1155/2012/519084

Stikic R, Glamoclija D, Demin M, Vucelic-Radovic B, Jovanovic Z, Milojkovic-Opsenica D, Jacobsen S-E, Milovanovic M (2012) Agronomical and nutritional evaluation of quinoa seeds (Chenopodium quinoa Willd.) as an ingredient in bread formulations. J Cereal Sci 55:132-138. doi:10.1016/j.jcs.2011.10.010

Tester M, Langridge P (2010) Breeding technologies to increase crop production in a changing world. Science 327:818-822. doi:10. 1126/science. 1183700

MDRyT [Ministerio de Desarrollo Rural y Tierras] (2009) Política nacional de la quinua. Consejo Nacional de Comercializadores y Productores de Quinua [CONACOPROQ], pp 134. http://www. bolivia.de/fileadmin/Dokumente/DestacadosEmpfehlenswertes Footer/PoliticaNacionalQuinua.pdf. Accessed 17 Feb 2013

Tran TA, Daim T (2008) A taxonomic review of methods and tools applied in technology assessment. Technol Forecast Soc Chang 75:1396-1405. doi:10.1016/j.techfore.2008.04.004

Turquisefoods (2009) Blue Poppy Seed. http://www.turquisefoods.com/ 2.html. Accessed 25 March 2013 
UNCTAD [United Nations Conference on Trade and Development] (2013) Trade and Environment Review 2013 - Wake up before it is too late. United Nations Publication, ISSN 1810-5432, pp 318

USGS [U.S. Geological Survey] (2013) Glyphosate herbicide found in many Midwestern streams, antibiotics not common. http://toxics. usgs.gov/highlights/glyphosate02.html. Accessed 20 Aug 2014

Uusiku NP, Oelofse A, Duodu KG, Bester MJ, Faber M (2010) Nutritional value of leafy vegetables of sub-Saharan Africa and their potential contribution to human health: a review. J Food Compos Anal 23(6):499-509. doi:10.1016/j.jfca.2010. 05.002

van den Ende J, Mulder K, Knot M, Moors E, Vergrath P (1998) Traditional and modern technology assessment: toward a toolkit. Technol Forecast Soc Chang 58:5-21, http://ocw.tudelft.nl/ courses/sustainable-development/technics-and-future/readings/? jumpurl=uploads $\% 2$ Fmedia $\% 2$ Ftechnologyandfuture. pdf $\&$ ju Se cure $=1 \&$ m ime Type $=$ application $\%$ 2Fpdf\&locationData $=6527 \% 3$ Att_content $\% 3$ A47299\&juHash= 08786b76439b1c4d337c2e96f99aa8b65a7bdb0d. Accessed 17 Feb 2013

Vavilov NI (1951) The origin, variation, immunity and breeding of cultivated plants. Chron Bot 13(1/6):1-366. doi:10.1126/science.115. 2990.433-a

Vavilov NI (1992) Origin and geography of cultivated plants. Cambridge University Press, Cambridge, ISBN 0-521-40427-4
Vavilov NI (1997) Five continents. IPGRI, Rome; VIR, St. Petersburg, pp 249, http://www.bioversityinternational.org/uploads/tx_news/419. pdf. Accessed 17 Feb 2013

Waghorn GC, Reed JD, Ndlovu LR (1999) Condensed tannins and herbivore nutrition. Proceedings of the XVIII International Grasslands Congress Vol III: 153-166. http://www.internationalgrasslands.org/ files/igc/publications/1997/iii-153.pdf. Accessed 25 March 2013

Welch RM, Graham RD (2004) Breeding for micronutrients in staple food crops from a human nutrition perspective. J Exp Bot 55:353364. doi:10.1093/jxb/erh064

WHO (2009) Global prevalence of vitamin A deficiency in populations at risk 1995-2005. WHO global database on vitamin A deficiency. WHO, Geneva, p 68, http://whqlibdoc.who.int/publications/2009/ 9789241598019_eng.pdf?ua=1

WHO (2013) Chemical hazards in drinking-water-glyphosate and AMPA. http://www.who.int/water_sanitation_health/dwq/ chemicals/glyphosate/en/. Accessed 25 March 2013

Xhoxhi O, Pedersen SM, Lind KM, Yazar A (2014) The determinants of intermediaries' power over farmers' margin-related activities: evidence from Adana, Turkey. World Dev 64:815-827. doi:10.1016/j. worlddev.2014.07.012

Zanklan AS, Ahouangonou S, Becker HC, Pawelzik E, Grüneberg WF (2007) Evaluation of the storage root-forming legume Yam Bean (Pachyrhizus spp.) under West African conditions. Crop Sci 47: 1934-1946. doi:10.2135/cropsci2006.03.0153 